cease boiling. The ten minutes are reckoned from the moment the liquid begins to bubble freely.

The remarks of Dr. W. Roberts (NATtRE, Feb. 20, p. 302) do therefore not apply to these experiments. Moreover, I observed frequently the temperature in the month of the flask, and found it always to be between $95^{\circ}$ and $100^{\circ} \mathrm{C}$. Therefore no part of the flask escaped the full effect of the germ-destroying heat.

While the boiling continued, a heated piece of unglazed flat earthenware tile was then pressed on the mouth of the flask; the solidified asphalt melted, and the piece of tile adhered, after cooling, firmly to the mouth of the flask. No air could then penetrate to the interior, except through the pores of the closing tile. The tile was 7 millimetres thick.

The previous heating of the tile is necessary, not only for melting the asphalt, but also for destroying the germs which possibly may adhere to the tile itself. This heating is effected in a Bunsen's burner, and raises the temperature of the tile to such an extent that a tuft of cotton-wool is scorched brown when pressed against it. The tile should not be too hot when it comes on the asphalt, lest the fumes arising from the decomposition of the asphalt should spread to the interior of the flask, and hinder the production of Bacteria.

The flasks prepared in this way were then exposed in a water bath to a temperature of $30-35^{\circ} \mathrm{C}$. After two or three days the liquid was very turbid, very often a thick pellicle appeared on the surface, and flocky masses were swimming in the solution. The closing tile was then removed by melting the asphalt, and the microscopic examination showed myriads of Bacterium termo in lively motion, while the pellicle and the flocky masses consisted also of these organisms. Micrococcus crepusculum and Vibrio serpens were often present, but $B$. termo predominated. (The Bacteria were determined after Cohn's classification. "Beiträge zur Biologie der Pflanzen, II.")

The experiment conducted in this way yields always a positive result. Now three things are possible :-

r. The materials employed originally contained germs of Bacteria, which have simply developed themselves.

2. During the experiment germs have penetrated into the interior of the flasks.

3. The Bacteria have originated de novo in the liquid.

The first explanation is not admissible. For control-solutions treated exactly in the same manner, but composed in other proportions, remained under the same conditions perfectly free from Bacteria. These solutions were-

a. $100 \mathrm{c}$. c. of the above-named salt solution + I grm. ammonium-tartrate +1 grm. grape-sugar.

b. I00 c. c. of the salt-solution $+\mathrm{I}$ grm. ammonium-tartrate +0.2 grm. peptone.

Both these liquids are eminently suited to the nutrition and growth of Bacteria. That they nevertheless remained pure from these organisms proves that none of the naterials employed contained germs capable of resisting for ten minutes a temperature of $100^{\circ} \mathrm{C}$.

The second explanation is equally inadmissible. To prove this directly I grm. ammonium-tartrate was dissolved in 100 c.c. of the sa't solution. This liquid was equally divided in two flasks, $A$ and $B$. To $A$ was added a trace of air-dust, collected in a little room where putrefying liquils were often standing, and then the fask was close 1 with a piece of tile in the abovedescribed manner. B was boiled and closed as usual; but on the upper surface of the closing tile a considerable quantity of the same dust was loosely strewn. After twenty-four hours A becomes turbid, and swarms on the third day with Bacteria ; B is on the eighth day still perfectly clear, and is then no longer examined. The conclusion is obvious : no germs of Bacteria do pass through the pores of the tile.

The only remaining explanation, is, in my opinion, this : under the above-described circumstances, Bucteria can arise without pre-existing germs. Not in any single case have I seen any other organisms than Bacteria-never fungi.

A certain concentration of the liquid is an important desideratum in these experiments. A specific gravity of about $\mathrm{I}^{\circ} \mathrm{OI} 2$ is the most favourable. Greater dilution is a hindrance as well as greater concentration-at least when the above-ramed materials are employed. It is, however, not absolutely necessary to employ grape-sugar for raising the specific gravity up to I'Or 2 . Common salt can do this just as well. Thus the following mixture is equaliy sufficient for generating Bacteria :- Ioo c.c. of the above-named salt solution, 2 grm. common salt, $0^{*} 2$ grm. grape-sugar, $0^{*} 4 \mathrm{grm}$. peptone.
The first thing to be done now is to substitute for the grape-sugar and the peptone less complicated bodies. My experiments have been continued with this purpose.

This brief abstract may suffice for the moment. Shortly a more detailed communication and discussion will appear in one of the special journals. D. HUIZINGA,

Professor of Physiology at the University of Groningen

Groningen, March 15

\section{The Janssen-Lockyer Method}

SINCE my letter which appeared in NATURE of February 20 there has been a letter from Dr. Huggins (also in NATURE, February 27, p. 320), and I see that Mr. Richard A. Proctor has likewise published a letter in the English Mechanic of March 7 .

With respect to the former of these communications I have but one remark to make. I was ignorant that the domestic bereave. ment to which Dr. Huggins alludes occurred at the time when the eclipse reports from India reached this country. This circumstance undoubtedly explains why Dr. Huggins did not sooner make the observation ailuded to; and had $I$ known the coincidence in point of time between these two events I should not have made the remark to which he refers.

Mr. Proctor's letter certainly surprises me, especially as coming from one who holds a prominent official position in the chief astronomical society of this country.

I. In the first place I cannot understand what Mr. Proctor means when he says with allusion to the question proposed by Mr. Lockyer in his preliminary paper of 1866 - "I have always judged from the form of the query that, as he now mentions, Dr. Stewart had suggested its wording." If Mr. Proctor will refer to my letter in NATURE of February 20 be will find it stated that $I$ advised Mr. Lockyer to introduce-his views in the shape of a question, which he accordingly did. The wording was Mr. Lockyer's own, being the result of his own cogitations on the subject, and all that $I$ did was to suggest the putting of it in the form of a question.

2. Nor can I understand what Mr. Procior means when he says- "I can admit very readily that Mr. Lockyer clearly recognised the principle of the method for spectroscopically studying the prominences when he asked the query. I do not indeed see how any person at all familiar with spectroscopic analysis could have failed to do so, after reading Dr. Huggins' account of his observations of T Coronæ."

When Mr. Lockyer suggested the application of the spectrcscope to the sun's red flames he knew, no doubt, and made use of his knowledge, that in white solar light the spectrum is scattered, while in light from incandescent gases it is not; but his information on these points was not surely derived from $\mathrm{Mr}$. Huggins. Was not Newton the first to show that a slit of white light is dispersed by refraction into a broad band or ribbon? I do not know whether Newton ever clearly enunciated that in consequence of this dispersion the ribbon was less luminous than the slit. Perhaps he thought that this was sufficiently understood, but at any rate he who after Newton first made this announcement cannot be said to have made a very startling discovery. I have the highest respect for the brilliant discoveries of Dr. Huggins, but I am quite sure that he does not claim as one of these the statement that "when the feeble light of a nebula is dispersed into a spectrum consisting of light of all refrangibilities, the spectrum is extremely faint."

In like manner the man of science who first showed that incandescent gases give out only a few spectral lines marle a great discovery; while he who after this discovery firse announced that such light will not be weakened by dispersion can hardly be said to have made a discovery at all.

Now theso two discoveries of two different kinds of spectra have been most prolific. Swan has used them; Kirchboff has used them in certain experiments of his in which the conditions were probably very similar to those in $\mathrm{T}$ Coronæ, and after Kirchloff, Huggins, and after Huggins, Lockyer. Each of these and many more have applied those well-known principles in many ways, none of the observers claiming the principles, but 6 ach one claiming his own application, being at the same time perfectly willing to acknowledge his neighbour's just claims. For instance, Dr. Huggins says-" "To Mr. Lockyer is due the first publication of the idea of the possibility of applying the spectroscope to observe the red flames in sunshine." Now this is precisely the state of the case, and I need not say anything more.

3. Then as to the advice to Mr. Lockyer to put his suggestion in the shape of a query, it ought to be remarked that it was a 
preliminary paper, and that $\mathrm{Mr}$. Lockyer intended to follow up and did follow up his suggestion with the requisite observations. But at that time neither Mr. Lockyer nor myself knew to what extent the spectroscope would throw light upon these red flames. What service I did was in stating my opinion that those red flames were probably gases, while the suggestion as to how to detect them was due to Mr. Lockyer. Had the red flames proved to be solid particles, the spectroscope would have afforded only meagre negative evidence of their existence.

Our ignorance on this point suggested to us the propriety of a query. It was only in this respect that the query was ambiguous, that is to say there was no doubt that the method suggested by Mr. Lockyer would throw a great deal of light upon the red flames if they proved to be gaseous, but the only doubt in our minds was whether or not they were gaseous.

4. I have tried as well as I can in justice to both of us, to remember and reproduce what took place in the conversation in 1866 between Mr. Lockyer and myself, and to show the reasons for the form in which $\mathrm{Mr}$. Lockyer's suggestion was put. Probably Mr. Huggins announced it afterwards in a more complete form, and probably it has since been announced in a yet more clear and complete form, if this be possible. For we know that as a rule discoverers and inventors have no great power of expression, and if the prize is to be given for the clearest possible utterance of a truth, it will be very seldom won by the discoverer, but will very frequently be obtained by the popular writer. Nevertheless I fail to see that Mr. Lockyer's original query was at all ambiguous in the sense that Mr. Proctor suggests. How, I should like to know (adopting the words of the query), could the spectroscope afford us evidence of the existence of the "red flames at other times than those of a total eclipse, unless by dispersing the reflected light."

5. Mr. Proctor asks, To what end are we to inquire whether Mr. Lockyer would or would not have detected the lines without the information derived from the eclipse observations? As far as I can understand the question I quite agree with Mr. Proctor. 1 do not think the inquiry ought ever to have been made. When, however, it was suggested that Mr. Lockyer derived aid from the Indian observations it was surely allowable for him to deny the imputation.

6. I have sometimes thought that discussions too frequently arise from the attempt to compare together the labours of differeut men, when all that is necessary is a statement of facts and dates. It is a matter of fact that the Indian observers at a particular date and under particular circumstances, made certain observations and derived certain results. It is likewire a matter of fact that $\mathrm{Mr}$. Lockyer, at a date slightly later and under cer ain other circumstances, made observaions of another kind, from which he also derived certain results. Different minds are differently constituted; one will think more of the Indian observations, another of those of Mr. Lockyer. But why should the two be compared together, unless some good object is to be gained by the comparison?

7. Now I cannot see why Mir. Proctor in his letter should have made the comparison at all, but since he has done so, I must be allowed to object to his method of making it. "Surely," he says, "on this matter we must assign Mr. Lockyer only the credit arising from the fact that, possessing an instrument which made the work child's play, he saw the lines by the method de. scribed by Huggins nine months before in detail, and depending on a principle which Huggins had stated fully two years and nine monch before." I have already endeavoured to dispose of the latter part of the statement, and indeed Mr. Huggins has disposed of it himself; but with regard to the first part of it, I conceive that the possession of ar instrument which made the work child's play, forms one element of the credit due to Mr. Lockyer. At first his instrument was defective and unable to do what he wished, but his conviction that something was to be made out of the sun, if examined by a powerful spectroscope, was so strong, that after much delay on the part of the optici.n employed, and sundry other discouragements, he at last procured tor himself an iustrument with which he saw the red flames at the very first trial.

8. I should io. have alluded to the concluding paragraphs of Mr. Proctor's letter were it not written by one who holds a high official position in the Royal Astronomical Society. To my mind it is most deplorable that the secretary of this society should conceive himself at liberty to make in a public journal unsupported statements reflecting discreditably upon a distin. guished member of that society. It is bad enough when two private men of science abuse each other, but it is not to be tolerated when a high official of a society of standing descends into the arena. If he insists upon doing so it is surely not unreasonable to request that he will in the first place divest himself of his robes of office.

For my own part I have thought that Mr. Lockyer has attached only too much importance to the little help I gave him when we conversed together in $\mathbf{I} 866$.

\section{BaLfovr Stewart}

\section{Mr. Mallet's Theory of Volcanic Energy}

WiLl you allow me to make a few remarks upon Mr. David Forbes's critique, which has but just now met my eye, though published in NATURE of February 6 last, upon my translation of Prof. Palmieri's "Incendio Vesuviano," and more especially upon that gentleman's animadversions upon my views as to "the true nature and origin of volcanic heat and energy," a brief and incomplete account of which I have given in the "introductory sketch" prefaced by me to that translation.

Mr. Forbes commences (p. 260) with an important error as to a matter of fact, by referring to "Mr. Mallet's Dynamical Theory of Volcanic Energy," as published in the Proceedings of the Royal Society for 1872 .

My paper as above was read in abstract only in June last to the Royal Society, and being reserved for probable publication in the Phil. Trans., nothin ${ }^{\prime}$ but the most meagre and incomplete abstract has appeared in the Proceedings of the Ruyal Society.

I have given a somewhat fuller, but still most incomplete, account of it in my "introductory sketch" above referred to. My paper, and the full statement of $m y$ views, with the proofs which give them validity, have thus as yet never been published at all, nor even verbally stated publicly, the paper being stull-after eight months, I regret to say -in the hands of the referees.

When published-as the paper in some form will no doubt be - Mr. Forbes will find that his objeciions-so far as I can gather anything tangible from their statement in NArURE--have been anticipated, and I believe completely answered, in my paper, along with others, better founded, because based on fact, which, as it appears to me, Mr. Forbes's objections are not.

Mr. Forbes uses "theory" and "hypothesis" as though quite the same (p. 260). My hypothesis is simply undeniable, being no more than that our globe is a terr-aqueous planet subject to secular refrigeration; and upon that hypothesis I have built up my theory, that the evolution of volcanic heat is a necessary result, upon acknowledged physical laws of such refrigeration; and that from such heat so evolved-as the frimum motile - come in train all the other recognised volcanic phenomeua : chemical, as in the fusion and combination of the constituents of rocks into definite and indefinite compounds, decomposition of many solid, liquid, and gaseous bodies; mechanical in the elevation and throwing out at volcanic vents of all or any of these: water, air, and the chemical elements known to exist in the crust of our earth being the only conditions needed, in addition to heat, to account for all that we know as to volcanic phenomena, as now active in our planet.

I claim to have been the first to apply " measure, number, and weight" to volcanic theory; and when men of science generally shall have had access to my statements, I trust it will be admitted that I have not shrunk from rigidly testing by calculation the adequacy of the source I assign for volcanic heat, nor of the mechanism through which its subsequent effects are produced, as seen in volcanic phenomena. I am at the disadvantage that I cannot expect to cumber your pages by reference to those proofs-they are the less necessary here, however-inasmuch as my reviewer, though affecting to discredit the adequacy of the origin I assign for the "quantity of heat requisite to melt up such vast volumes of rock matter as are known to proceed from volcanoes," does not present a single argument against it, and, in fact, appears unwillingly to admit it. He however proceeds to object generally to my views by the following statements. They are so vague and inconsecuive that, as far as possible. I shall endeavour to condeuse them in his own words : -"Admitting that the conversion of the mechanical force into heat is sufficient to effect the melting part of the operation, there remains the greater diffeculty of explaining the chemical and mineralogical features which characterise volcanic phenomena. For although mechanical force is admitted to be convertible into its equivalent heat, which in turn may 'cause' chemical action, still no such forces, alone or in combination, can transmute one 